Marijana R. Aleksić ${ }^{*}$

УДК

Filološki fakultet

371.3:[81'255

Univerzitet u Beogradu

ДОИ

https://doi.org/10.18485/analiff.2016.28.2.12

\title{
STICANJE PREVODILAČKE KOMPETENCIJE NA UNIVERZITETSKIM STUDIJAMA ŠPANSKOG JEZIKA U SRBIJI**
}

\begin{abstract}
Budući da u Srbiji na akademskom nivou još uvek ne postoje programi za obrazovanje profesionalnih prevodilaca, u ovom radu želeli smo da ukažemo na značaj kurseva prevođenja na univerzitetskim studijama stranih jezika. Predstavili smo kako izgledaju kursevi prevođenja sa španskog na srpski jezik na Filološkom fakultetu u Beogradu i na Filološko-umetničkom fakultetu u Kragujevcu, budući da su to jedine akademske institucije na kojima postoji nastava prevođenja za španski jezik. Kursevi su dobro koncipirani, ali smatramo da bi ih, u nedostatku akademskih programa za profesionalne prevodioce, trebalo proširiti.
\end{abstract}

Ključne reči: nastava prevođenja; obuka prevodilaca na studijama stranih jezika; profesionalni realizam; komentarisani prevodi; studentska praksa

\section{Uvod}

Obuka prevodilaca počela je na univerzitetima u Moskvi (1930), Hajdelbergu (1933), Ženevi (1941) i Beču (1943), a drugi talas otvaranja takvih institucija u Evropi usledio je posle Drugog svetskog rata (Kelly, 2005: 8). Sistematično, akademsko obrazovanje prevodilaca nastupa od osamdesetih godina prošlog veka (Liu, 2013: 127). Međutim, uprkos tome, u mnogim zemljama i danas se ovom delatnošću bave bilingvalni govornici, samouki u oblasti prevođenja, ili oni neformalno obučeni uz pomoć

Studentski trg 3, 11000 Beograd, alek.marijana@gmail.com

Istraživanje predstavljeno u ovom članku sprovedeno je za potrebe master rada odbranjenog na Filološkom fakultetu u Beogradu školske 2014/2015. godine pod mentorstvom prof. dr Jelene Rajić. 
starijih i iskusnijih kolega (Kelly, 2005: 8). U Srbiji, konkretno za španski jezik, postoje brojni kursevi za obuku prevodilaca, ${ }^{1}$ ali jedine akademske institucije u okviru kojih je dostupna nastava prevođenja za pomenuti jezik jesu Filološki fakultet u Beogradu i Filološko-umetnički fakultet u Kragujevcu. Upravo ta činjenica navela nas je da se bavimo ovom temom.

Da bismo bolje sagledali problem, anketirali smo studente na Katedri za iberijske studije na Filološkom fakultetu u Beogradu i na Katedri za španski jezik i hispanske književnosti na Filološko-umetničkom fakultetu u Kragujevcu. Cilj ankete bio je da se utvrdi kako izgleda nastava prevođenja sa španskog na srpski jezik. Pritom nismo zanemarili činjenicu da glavni cilj ovih fakulteta nije obrazovanje profesionalnih prevodilaca već profesora jezika i književnosti.

\section{Značaj definisanja termina prevodilačka kompetencija za nastavu prevođenja}

Prema Kembelu (Campbell, 1998: 163), prevodilačka kompetencija se može raščlaniti na komponente čiji bi razvoj trebalo da predstavlja zasebne blokove u okviru nastave prevođenja, a cilj obrazovanja ili obuke prevodilaca treba da bude usvajanje pojedinačnih potkompetencija. Keli (Kelly, 2002: 9 - 10) deli Kembelovo mišljenje i smatra da definisanje prevodilačke kompetencije vodi ka uspešnom organizovanju nastave prevođenja. Uz dobru definiciju lakše se mogu osmisliti i primeniti aktivnosti koje dovode do valjanog razvoja svih potkompetencija.

O sposobnostima koje treba da poseduje profesionalni prevodilac autori su počeli da govore poslednjih decenija XX veka (Vid. Kelly, 2002: 10 - 13). Do danas najtemeljniji model prevodilačke kompetencije verovatno je izložila Doroti Keli. Taj model posebno je značajan za nastavu, jer je njegov cilj uspešna izrada planova i programa. Autorka govori o sledećim potkompetencijama: komunikativnoj i tekstualnoj na najmanje dva

$1 \quad$ Na primer, kursevi prevođenja za španski jezik postoje na Institutu Servantes, u školama Granada, Multilingua i Master Translation, kao i u drugim privatnim školama. S druge strane, u Udruženju naučnih i stručnih prevodilaca Srbije i u Udruženju sudskih i stručnih prevodilaca Srbije dobili smo informaciju da se nažalost ne organizuju kursevi prevođenja za taj jezik (personal communication, 25. 9. 2015). 
jezika (subcompetencia comunicativa y textual); kulturnoj, koja se pored enciklopedijskog znanja odnosi i na mitove, verovanja, način ponašanja, razmišljanja itd. (subcompetencia cultural); predmetnoj, koja podrazumeva vladanje tematikom (subcompetencia temática); instrumentalnoj, koja se odnosi na uspešno rukovanje svim vrstama priručnika, rečnika, baza podataka, odgovarajućeg softvera itd. (subcompetencia instrumental profesional); psihofiziološkoj, koja se tiče svesti o tome šta znači biti prevodilac, sposobnosti pamćenja, održavanja pažnje, samopouzdanja itd. (subcompetencia psicofisiológica); interpersonalnoj, koja podrazumeva veštinu komunikacije, ne samo s kolegama već i s klijentima i autorom teksta (subcompetencia interpersonal); strateškoj, koja se tiče prepoznavanja prevodilačkih problema, potrage za rešenjima, kao i vrednovanja sopstvenog prevoda (subcompetencia estratégica) (Kelly, 2002: 14 -15, 17 -18).

\section{O istraživanju}

kao što smo već naveli, Filološki fakultet u Beogradu i Filološko-umetnički fakultet u Kragujevcu jedine su akademske institucije u Srbiji u okviru kojih budući prevodioci za španski jezik mogu steći znanje. Zato nam je glavni cilj da ukažemo na značaj kurseva prevođenja na tim fakultetima:

Naročito kada nedostaju profesionalne škole i univerzitetski kursevi za obuku prevodilaca na državnom nivou, prevođenje inkorporirano u univerzitetski kurs stranog jezika može da posluži da se studentima omogući usvajanje osnova prevodilačkog procesa, da im se pruži uvid u složenu djelatnost prevođenja i baza za dalje profesionalno usavršavanje u tom pogledu. (Piletić, 2013: 29)

Od početka istraživanja bili smo svesni da nastava prevođenja u Beogradu i Kragujevcu nije u potpunosti stručno-didaktičkog tipa. Naime, na univerzitetskim studijama stranih jezika nastava prevođenja ima karakteristike i glotodidaktičkog, tj. pedagoškog prevođenja, koje je u službi unapređivanja jezičke kompetencije, i stručno-didaktičkog prevođenja, u kojem je jezička kompetencija već razvijena, te se teži profesionalnom prevodu (Piletić, 2013: 28). Uprkos tome, verujemo da bi pomenuti fa- 
kulteti trebalo da nadomeste nedostatak akademskih programa za obuku prevodilaca.

Istraživanje je sprovedeno na Katedri za iberijske studije na Filološkom fakultetu u Beogradu i na Katedri za španski jezik i hispanske književnosti na Filološko-umetničkom fakultetu u Kragujevcu, a fokus je bio na kursevima prevođenja sa španskog na srpski jezik. Zamišljeno je da se anketiraju studenti četvrte godine, jer bi oni mogli da sagledaju sve kurseve tokom osnovnih studija, što pojedina pitanja zahtevaju. Međutim, u Kragujevcu to nije bilo izvodljivo iz tehničkih razloga, te su anketu popunili studenti treće godine. Shodno tome, budući da imaju pred sobom još jednu školsku godinu, treba imati u vidu da njihovi odgovori na neka pitanja nisu sasvim relevantni. S druge strane, može se uzeti u obzir i to što su anketirani studenti u Kragujevcu dosad ipak imali godinu dana više nastave nego studenti u Beogradu. Naime, u Kragujevcu nastava prevođenja traje četiri godine, a u Beogradu svega dve. Anketa je urađena u saradnji sa profesorima na kursevima prevođenja sa španskog na srpski jezik u letnjem semestru školske 2014/2015. godine, a u istraživanju su učestvovali studenti koji su na dan anketiranja prisustvovali času na kojem je anketa sprovedena. Ukupan broj ispitanika u Beogradu iznosi 42, a u Kragujevcu 27.

\section{Pregled rezultata i predlozi}

\subsection{Broj semestara posvećen prevođenju i oblik nastave}

"Had translation depended for its survival on theory, it would have died out long before Cicero"

(Louis G. Kelly, 1979: 219)

Jedna od osnovnih razlika u nastavi prevođenja u Beogradu i Kragujevcu jeste broj semestara. U Beogradu kursevi prevođenja počinju na trećoj godini, te su im posvećena svega četiri semestra, dok u Kragujevcu traju tokom celih osnovnih studija. Veći broj semestra pruža mogućnost za raznovrsnije gradivo. S druge strane, nameće se pitanje jezičke kompetencije koja je potrebna za obavljanje tog zadatka. Ipak, 68,3\% ispitanika u Beogradu smatra da nastava prevođenja treba da se izvodi od samog početka studija, a 12,2\% obeležilo je opciju „možda“. Zanimljiv je podatak da je veliki broj ispitanika koji su odrično 
odgovorili na ovo pitanje ili obeležili opciju „možda“ (tačnije 38,5\%) takođe naveo da nisu odviše zainteresovani za prevođenje. U Kragujevcu samo dva anketirana studenta smatraju da nastava treba da počne na kasnijim godinama, te se zaključuje da studenti Filološko-umetničkog fakulteta pretežno pozitivno ocenjuju izvođenje nastave prevođenja tokom svih osam semestara. Dakle, stiče se utisak da se nastava uspešno odvija bez obzira na nedovoljno razvijenu jezičku kompetenciju.

Na pitanje da li su imali i teorijsku i praktičnu nastavu, $96,2 \%$ ispitanika u Kragujevcu odgovorilo je ,i teorijsku i praktičnu“. Studenti Filološkog fakulteta u Beogradu bili su manje složni, pa su njihovi odgovori podeljeni: $54,8 \%$ ispitanika navelo je da su imali i teorijsku i praktičnu nastavu, dok je $45,2 \%$ studenata obeležilo opciju ,samo praktičnu“.

Premda citat s početka govori o nezavisnom postojanju teorije i prakse, složićemo se sa Garsiom Lopes (García López, 2001: 243 - 244), autorkom koja govori o značaju teorijskog uvoda. Isto tako, Piletić odgovorno tvrdi: „Većina savremenih autora jednoglasna je u tvrdnji da će budući profesionalni prevodioci biti odgovorniji, uspješniji i sigurniji u donošenju prevodilačkih odluka, ukoliko se u periodu njihovog obrazovanja prevodilačka kompetencija razvija u teorijskim okvirima" (2013: 203). U skladu s tim, smatramo da treba razmotriti mogućnost uvođenja početnog kursa teorije prevođenja u prvoj godini. Verujemo da bi se tako postavile dobre osnove za praktičnu nastavu koja bi mogla da se odvija od druge godine. Takođe, u trećoj i četvrtoj godini prevođenje bi moglo da bude izborni predmet kako bi se na njega usmerili samo studenti koji su zaista zainteresovani za tu oblast. Na taj način bi se broj studenata u grupama smanjio, u nastavi bi učestvovali samo najmotivisaniji, pa bi i ishodi bili bolji.

\subsection{Zastupljenost različitih vrsta prevođenja u nastavi}

Kada je reč o zastupljenosti različitih vrsta prevođenja u nastavi, studenti su se jednoglasno složili da se najčešće prevode književni tekstovi (100\% ispitanika i u Kragujevcu i u Beogradu). Sledi praktična nastava stručnog prevođenja (97,1\% u Beogradu i 47,1\% u Kragujevcu). Treba uzeti u obzir to što je anketa u Kragujevcu sprovedena među studentima treće godine, te su dva ispitanika navela da se stručnim prevođenjem intenzivnije bave u četvrtoj godini. Profesorka je takođe istakla da se prema nastavnom planu i programu u trećoj godini započinje obrada stručne 
tematike, a da se u četvrtoj radi terminologija Evropske unije (I. Nikolić, personal communication, 8. 5. 2015).

Što se tiče usmenog prevođenja, u Kragujevcu je 52,9\% ispitanika obeležilo teorijsku nastavu konsekutivnog prevođenja i 29,4\% praktičnu. Budući da prevodioci kod nas nemaju priliku za stručnije usmerenje na akademskom nivou, u Kragujevcu je u nastavu uključeno konsekutivno prevođenje, premda to nije predviđeno planom i programom, te studenti na Filološko-umetničkom fakultetu imaju:

osnove iz konsekutivnog prevođenja, s praktičnim delom za one studente koji to žele (tj. oni koji žele da se okušaju u konsekutivnom prevodu ostaju petnaestak minuta duže na času, ostali mogu da idu). Kao pripremne vežbe za usmeno prevođenje radimo prevod s lista, usmeno parafraziranje tekstova, rezimirani prevod audio-vizuelnih materijala, kao i konsekutivni prevod audio ili audio-vizuelnih materijala. Iako tehnički nemamo opremljene učionice, nekako se snalazim da skoro na svakom času imaju neku tehnološku podršku audio ili audio-vizue$\operatorname{lnog}$ tipa. (I. Nikolić, personal communication, 8. 5. 2015)

S obzirom na to da se ne može pretpostaviti kojim vrstama prevođenja će se studenti baviti po završetku studija i imajući u vidu da je moderno tržište promenljivo, kod studenata treba razvijati fleksibilnost ka različitim vrstama tekstova, tj. treba ih osposobiti za efikasno pretraživanje novih domena (AlQinai, 2011: 22). Dakle, na kursu prevođenja treba postaviti osnove za dalje samostalno usavršavanje (Mayoral Asensio, 2003). O tome govori i Borislava Eraković, predavač na Katedri za anglistiku u Novom Sadu. Eraković ističe da „specijalizacija u prevođenju [...] nije ekonomski održiva ni za honorarnog prevodioca ni za prevodilačku agenciju“ (2010b: 94). Svakako, nijedan studijski program ne može obuhvatiti sve oblasti s kojima se kasnije, kao profesionalni prevodioci, studenti mogu susresti (Kelly, 2008: 254), ali se ipak mogu postaviti temelji za heurističko učenje (Mayoral Asensio, 2003).

Keli (2008: 251) izdvaja profesionalni realizam kao jedan od posebno bitnih faktora u nastavi prevođenja, a naročito u kasnijim fazama učenja. Profesionalni realizam podrazumeva, između ostalog, autentičnost nastavnog materijala, poštovanje dogovorenih rokova i simuliranje stvarnih prevodilačkih situacija u učionici. Reč je, dakle, o situacijama 
u kojima se profesionalni prevodilac zaista može naći, te su one ključne za formiranje mladih stručnjaka. U kontekstu tipologije tekstova koji se koriste u nastavi, to znači da treba prevoditi tekstove za kojima postoji potražnja na lokalnom prevodilačkom tržištu (Kelly, 2008: 252). S druge strane, važno je naglasiti da s pedagoškog stanovišta profesionalni realizam treba primenjivati tek u kasnijim fazama, a da spočetka treba koristiti tekstove pisane po određenom obrascu, kao što su kulinarski recept, tekst iz turističke brošure ili oglas (Kelly, 2008: 251, 254).

Verujemo, dakle, da studentima treba pružiti dobre osnove iz različitih vrsta prevođenja, što bi im olakšalo samostalno proširivanje znanja u oblastima za koje su zainteresovani. Određen broja časova mogao bi da se održi u kompjuterski opremljenoj sali kako bi kursevi obuhvatili i audio-vizuelno prevođenje. Kako navodi Sereso Merćan (Cerezo Merchán, 2013: 174), s obzirom na to da svi programi za prevođenje titlova funkcionišu slično, sasvim je opravdano koristiti besplatne. Profesionalni programi su pre svega skupi, a mana im je i to što bi se mogli koristiti samo u učionici, te im studenti ne bi imali pristup i od kuće. Takođe, budući da je Filološki fakultet nedavno dobio kabine za prevođenje, u nastavni plan i program može se uključiti i simultano prevođenje. Čak i ako bi se radilo o malom broju časova, to iskustvo bi bilo dragoceno onima koji će se baviti tom vrstom prevođenja.

\subsection{Uobičajeni čas}

$$
\begin{aligned}
& \text { "It is mainly in the classroom where the seeds are planted, } \\
& \text { horizons get opened and students are inspired“" }
\end{aligned}
$$

(Furmanek, 2010: 82)

$\mathrm{Na}$ osnovu odgovora ispitanika u Beogradu zaključuje se da na čas dolaze s unapred pripremljenim prevodom koji iščitavaju s ciljem da zajedno s profesorom dođu do najprikladnijeg rešenja. Studenti, dakle, složno odgovaraju na pitanje o tipičnom času:

Ispitanik 1: Pripremimo prevod teksta kod kuće i onda na času upoređujemo rešenja.

Ispitanik 2: Već preveden tekst se obrađuje sa profesorom. Učestvuje cela grupa, jedan po jedan. Profesor objašnjava zašto je ispravan ili neispravan određeni prevod.

Ispitanik 3: Svaki učenik pročita po jednu rečenicu i prevede je, a 
profesor pita za druga rešenja, odobri prevod ako je tačan i sugeriše još neka moguća rěsenja.

Na Filološko-umetničkom fakultetu primenjuje se isti sistem rada, ali, pored provere prevoda, zastupljene su i druge vrste zadataka:

Ispitanik 1: Počnemo sa vežbanjima koje profesorka pripremi (prevod reči, izraza, poslovica...), zatim radimo prevod koji smo imali za domaći, proziva kako ona želi.

Ispitanik 2: Uglavnom imamo fotokopije u vezi sa vokabularom, radimo tekst koji smo imali za domaći; kreativan kraj časa koji uključuje muziku, film...

Ispitanik 3: Na početku časa radimo rečenice, poslovice, razne vežbe, zatim prevodimo tekst, a nekad gledamo neke serije i slušamo muziku $i$ pokušavamo da prevedemo što smo čuli.

Odgovori ispitanika potvrđuju tvrđenje Borislave Eraković (2010a: 42) da se obuka prevodilaca na katedrama za jezike u Srbiji zasniva na praktičnim kursevima gde se prevodilačka kompetencija gradi induktivnim putem, kroz greške. Međutim, Kirali (Kiraly, 1995: 11) veruje da je ukazivanje na greške zbog kojih prevod nije ,idealan“, uz očekivanje da se te greške ubuduće ne ponavljaju, zapravo tradicionalan pristup nastavi. Isto tako, Keli (2010: 389) tvrdi da je tačno da je dugo vladalo mišljenje da studenti uče da prevode imitirajući način na koji to radi profesor, ali da zapravo nije tako. Majoral Asensio (Mayoral Asensio, 1993) takođe ukazuje na to da se prevođenje ne uči jednostavnim posmatranjem načina na koji prevodi nastavnik. Autor dodaje da to jeste jedan od mnogih izvora za sticanje i usavršavanje znanja, ali da nije najbolji. U tom kontekstu Kirali i Keli navode kako Haus opisuje tipičan tradicionalni čas:

The teacher of the course, a native speaker of the target language, passes out a text (the reason for the selection of this text is usually not explained, because it is often a literary essay that the teacher has just "found" by accident). [...] The text is then prepared, either orally or in written form, for the following sessions and then the whole group goes through the text sentence by sentence, with each sentence being read by a different student. The instructor asks for alternative translation solutions, corrects the suggested versions and finally presents the sentence in its final, "correct" form. [...] This procedure is naturally very frustrating for the students. (House, 1980: 7 - 8, prema Kiraly, 
1995: 7 \& prema Kelly, 2010: 389)

Profesor prevođenja na Univerzitetu u Lionu, Danijel Žil (Daniel Gile, 2004) razvio je model nastave pod nazivom Integrated Problem and Decision Reporting. I sam Žil navodi da je komentarisanje prevodilačkih problema i načina na koji se oni mogu rešiti na času uobičajena praksa. Njegov metod se, međutim, razlikuje po tome što su komentari o problemima u tekstu, koracima koji su preduzeti da se oni reše i razlozima za donošenje određenih prevodilačkih odluka sastavni deo zadatka studenata (Gile, 2004: 3). Uz takav izveštaj fokus je na samom procesu prevođenja, a ne na prevodu kao krajnjem proizvodu (process-oriented teaching appro$a c h)$. Takav pristup posebno je važan u radu sa studentima na početnim kursevima. Studenti predaju izveštaje u pisanoj formi, na osnovu čega profesor priprema rezime za naredni čas, kada se vodi diskusija o problemima u tekstu i mogućim rešenjima (Gile, 2004: 6 - 7).

Takav metod primenjuje Borislava Eraković na Katedri za anglistiku na Filozofskom fakultetu u Novom Sadu. Od studenata se očekuje da u dnevnik pribeleže relevantne podatke o problemima s kojima se susreću u toku prevođenja. Dužni su da objasne zašto su, suočeni s nekim prevodilačkim problemom, postupili na određeni način i koje su izvore koristili. Takav metod rada Eraković dopunjuje upotrebom paralelnih i ilustrativnih tekstova. Komentari, $\mathrm{tj}$. dnevnici, predaju se pre časa, a potom se $\mathrm{u}$ grupama piše konačna verzija prevoda na osnovu koje se dobijaju povratne informacije (Vid. Eraković, 2010a).

Prednosti komentarisanih prevoda su brojne. Dnevnik se smatra alatkom koja pruža dragocene podatke o individualnom napretku studenata, koji se ne može pratiti na osnovu usmene provere prevoda na času (Eraković, 2013: 149). Osim toga, dnevnici omogućavaju organizovanje diskusije o relevantnim prevodilačkim problemima (Eraković, 2010a: 46). Kako navodi Žil, ponekad se određeni leksički odabir ili struktura rečenice može učiniti pogrešnim, ali na osnovu uvida u relevantne izvore koji su navedeni u komentarima može se utvrditi suprotno. Isto tako, neretko je teško odrediti da li je u pitanju greška ili je upotrebljena tehnika koja bi u tom slučaju bila relevantna, premda ne bi bila izbor samog profesora. Takve nedoumice rešavaju se zahvaljujući komentarima. Takođe, ovaj metod podstiče studente da profesionalnije i ozbiljnije pristupe zadatku 
(Gile, 2004: 4 - 5, 8). Eraković (2010a: 44 - 45, 49 - 50) ukazuje na to da dnevnici omogućavaju uspostavljanje ravnoteže između pozitivnih i negativnih povratnih informacija. Naime, autorka veruje da se negativna kritika loše odražava na motivaciju, te da konstantno ukazivanje na greške ne utiče pozitivno na razvoj prevodilačke kompetencije. Zato je bitno „da povratna informacija sadrži bar isto onoliko pozitivnih komentara koliko i negativnih“ (Eraković, 2009: 175). Negativan stav o nastavi koja se zasniva na greškama imaju i drugi autori (npr. Kiraly, 1995; Kussmaul, 1995).

Rezultati ankete koju je Eraković sprovela pokazuju da studenti visoko vrednuju prevodilački dnevnik kao nastavno sredstvo. Ipak, autorka naglašava da je bitan teorijski uvod, jer se usled nepoznavanja osnovnih teorijskih pojmova mogu javiti poteškoće u prepoznavanju prevodilačkih problema i otpor prema toj aktivnosti (Eraković, 2010a: 46; 2010b: 93). U prilog tome idu i Žilovi (2004: 3) navodi da se već decenijama iz godine u godinu susreće sa zbunjenim studentima kojima nije jasno zašto i šta zapravo treba da urade, ali da se uvek ispostavi da kasnije reaguju pozitivno. Nedostatak se međutim ogleda u obimu posla koji nastavnici u tom slučaju imaju. Mada Žil (2004: 7) ističe da iščitavanje dnevnika oduzima manje vremena nego što se na prvi pogled čini, pregledanje osamdesetak radova iz nedelje u nedelju nesumnjivo je obiman posao. Na Katedri za anglistiku u Novom Sadu studenti rade u grupama, a korist je višestruka: razvija se interpersonalna kompetencija; prevod je znatno bolji, te će i povratne informacije biti bolje, što je značajno za motivaciju; razvijaju se veštine za efikasno obavljanje zadatka u određenom roku; i obim posla koji profesor ima znatno je manji (Eraković, 2010a: 47 -48).

\subsection{Uobičajeni ispit}

Što se tiče kolokvijuma i ispita, studenti Filološko-umetničkog fakulteta u Kragujevcu su naveli:

Ispitanik 1: Dobijemo tekst i prevodimo uz pomoć jednojezičnih rečnika, dozvoljeni su i dvojezični, ali ne špansko-srpski $i$ obrnuto.

Ispitanik 2: Kolokvijum obuhvata prevod teksta uz poželjni jednojezični rečnik (dvojezični su zabranjeni uglavnom). Ispit obično ima sličnu formu.

Ispitanik 3: Koristimo jednojezične rečnike na ispitu. Kolokvijumi su u vidu vežbi. 
Od studenata u Beogradu dobili smo sledeće odgovore:

Ispitanik 1: Dozvoljena je upotreba jednojezičnih rečnika. Na kolokvijumu se radi prevod poznatih tekstova (rađenih na časovima), a na ispitu se prevode nepoznati tekstovi.

Ispitanik 2: Kolokvijum: poznati tekstovi, prevod u paru ili individualno, cilj je da se utvrdi koliko je student redovno radio tokom semestra. Ispit: nepoznat tekst, prevodimo uz pomoć rečnika, daju se slične konstrukcije koje smo učili kako da prevedemo tokom semestra. Dozvoljeni su jednojezični rečnici (Clave, DRAE), eventualno rečnik sinonima.

Ispitanik 3: Dobije se tekst koji treba prevesti (na kolokvijumu su to odeljci iz tekstova koje smo radili na času, dok se na ispitu dobija nepoznat tekst). Koristi se jednojezični rečnik, osim u prvom semestru kada je bilo dozvoljeno korišćenje dvojezičnog rečnika.

$\mathrm{Na}$ tradicionalnim ispitima studenti nemaju pristup internetu, a od štampanih resursa dozvoljeni su samo jednojezični rečnici, što se znatno razlikuje od uslova u kojima rade profesionalni prevodioci, te ,prevod teksta $\mathrm{u}$ ispitnim uslovima nije reprezentativan pokazatelj usvojenih znanja“" (Eraković, 2010b: 91 - 92). S ovom tezom slaže se i Piletić, koja takođe objašnjava da je važno da ispitni uslovi nalikuju realnim situacijama:

Do sada i zasad, prilikom izrade prevodilačkih zadataka na kolokvijumu i ispitu, studenti imaju pravo da koriste jedino jednojezični rječnik, dok bi realna situacija zahtijevala upotrebu i dvojezičnog rječnika i pravopisnih priručnika, a što je najvažnije pristup internetu, kao prevodilačkom pomagalu bez kojeg danas nijedan prevodilac ne može zamisliti svoj rad. (Piletić, 2013: 67)

Osim toga, premda se mora zahtevati kvalitetan prevod, „apsolutni““ kvalitet krajnjeg proizvoda ne sme biti jedino što se ocenjuje. Posebnu pažnju treba obratiti na to koliko je student napredovao i da li su ostvareni ciljevi kursa (Kelly, 2008: 257). Na osnovu tradicionalnog načina ocenjivanja, analize grešaka, ne može se proceniti razvijenost prevodilačke kompetencije (Eraković, 2010b: 91). To omogućavaju komentarisani prevodi, te Eraković (2010b: 92 - 93) smatra da barem deo bodova studenti treba da ostvare „prevodom u slobodnim uslovima“. Autorka navodi da zadatak treba da obuhvata i pisanje komentara, zbog čega bi rok za predaju rada trebalo da bude nešto duži, na primer jedan do dva dana. Dakle, jedna 
od predispitnih obaveza može biti prevodilački dnevnik.

Ukoliko se na ispitima ne može omogućiti pristup elektronskim i štampanim resursima, prevod se može raditi i od kuće preko virtuelnih platformi, i to bez bojazni od mogućeg ,prepisivanja“.2 Kako objašnjava Keli (2002: 13), mada se tradicionalno zamišlja da prevodilac radi odsečen od sveta, okružen samo rečnicima, danas je u prevodilačkom zanatu komunikacija ključna. To znači da prevodilac može računati na saradnju stručnjaka u datoj oblasti, autora teksta i klijenta. Drugim rečima, kod studenta treba razviti svest o tome da prevodilac ne mora da zna sve (cf. Künzli, 2004; Samardžić, 2008; Katan, 2008).

\section{Studenska praksa}

"Although leading interpreter education programs are situated in an academic environment, interpreter training has never truly left the realm of apprenticeship"

(Sawyer, 2004: 76)

Studentska praksa je u direktnoj vezi s profesionalnim realizmom, te je veoma važan faktor za razvijanje prevodilačke kompetencije i nezaobilazna je u nastavi prevođenja (Eraković, Kampmark, \& Ivanović Muždeka, 2014: 533). O praksi kao bitnom elementu u nastavi govori i Kirali, koji naglašava da prevodilačka učionica ne sme prekinuti kontakt sa stvarnim profesionalnim svetom (Kiraly, 2000: 3). Za studente prevođenja postoje dva glavna oblika prakse, $i$ to posmatranje profesionalnog prevodioca na radnom mestu i samostalno prevođenje (Kelly, 2005: 92).

Drugi oblik prakse, samostalno prevođenje teksta namenjenog objavljivanju, omogućen je studentima na predmetu Traduktologija na master studijama na Filološkom fakultetu u Beogradu školske 2014/2015. godine. Jedna od predispitnih obaveza podrazumevala je prevođenje dramskog komada Tvoje tajno oružje za borbu protiv neukrotivog celulita, koji je objavljen u časopisu za pozorišnu umetnost Scena. Taj projekat istovremeno je primer uspešno primen-

2 Primer uspešno sprovedenog prevoda u slobodnim uslovima preko platforme Moodle s ograničenim trajanjem jeste zadatak koji su studenti master studija imali u okviru predmeta Traduktologija na Katedri za iberijske studije na Filološkom fakultetu u Beogradu školske 2014/2015. godine. 
jenih komentarisanih prevoda u nastavi (Kovačević Petrović, 2015: 81).

Priliku za samostalno prevođenje imali su i studenti na Katedri za anglistiku na Filozofskom fakultetu u Novom Sadu. Učešćem u radionici Prevođenje detektivskih priča Agate Kristi najbolji i najmotivisaniji studenti okušali su se u svom prvom ozbiljnom prevodilačkom poduhvatu. Priče su objavljene u izdanju Politike, kao besplatni dodatak listu, a izlazile su u prvom tromesečju 2014. godine, svakodnevno (Eraković, Kampmark i dr., 2014: 534 - 535, 537).

Uočeno je da motivacija studenta vrtoglavo raste kada se suoče $s$ autentičnim prevodilačkim zadacima, jer sama ideja da će njihov rad biti objavljen predstavlja veliki podstrek (Eraković, Kampmark i dr., 2014: 546 - 547; AlQinai, 2011: 24). Naime, kako podvlači Keli (2008: 255), profesionalni realizam sam po sebi dovoljno motiviše. Međutim, koordinatorke pomenute radionice ipak naglašavaju da je taj poduhvat potvrdio polaznu pretpostavku da studentska praksa ne treba da bude obavezna, već da studentima u tom pogledu treba dati mogućnost izbora. Pritom se, kako kažu, mora voditi računa da takva praksa, tj. volonterski rad, ne ugrozi profesionalne prevodioce na tržištu, što znači da studenti ne treba da učestvuju u profitabilnim projektima (Eraković, Kampmark i dr., 2014: 547).

U skladu s tim, moguće je uspostaviti saradnju s prevodilačkim agencijama. Studenti bi tako dobili dragocenu priliku da se upoznaju s poslom i da sarađuju sa starijim kolegama. Što se tiče književnog prevođenja, projekat poput Prevođenja detektivskih priča Agate Kristi verovatno bi većina dnevnih listova dočekala raširenih ruku, jer bi im se tiraž nesumnjivo povećao, a pritom ne bi imali izdatke za prevodioce. Mada takvi projekti imaju visok tiraž, oni ne ugrožavaju profesionalne prevodioce, jer prevodi nisu namenjeni prodaji već su besplatni dodatak listu (Eraković, Kampmark i dr., 2014: 547). Budući da su priče uključene u pomenuti projekat već bile prevedene, koordinatorke radionice ističu da je:

reakcija čitalaca Politike, vidljiva u povećanoj tražnji ovog lista tokom perioda u kom su objavljene priče (tiraž je porastao za oko 5000), dobar [je] pokazatelj da se u sferi ponovljenih prevoda može pronaći ta niša u kojoj će se afirmisati novi prevodioci ne ugrožavajući ionako osetljivo tržište književnog prevođenja. (Eraković, Kampmark i dr., 2014: 547)

\section{Zaključak}


Namera nam je bila da u ovom članku istaknemo značaj nastave prevođenja na univerzitetskim studijama stranih jezika. U istraživanju smo se usredsredili na kurseve prevođenja sa španskog na srpski jezik na Filološkom i Filološko-umetničkom fakultetu. Kursevi su dobro organizovani, ali verujemo da bi ih trebalo proširiti ukoliko postoje mogućnosti za to.

Kao posebno pohvalne aspekte nastave u Kragujevcu treba izdvojiti konsekutivno prevođenje, obradu terminologije Evropske unije i upotrebu audio-(vizuelnog) materijala. U Beogradu, naročito treba pohvaliti rad u parovima, koji je sa stanovišta razvoja interpersonalne potkompetencije veoma važan. Pohvale su verovatno najlepše sročili sami studenti:

$\underline{\text { Kragujevac }}$

Ispitanik 1: Što se tiče ovog kursa prevođenja na ovom fakultetu, ne treba ništa menjati. Sasvim dovoljno se radi, časovi su puni kreativnosti $i$ studenti su dovoljno motivisani.

Ispitanik 2: Časovi su inspirativni i svakako podstrek za dalji rad.

Beograd

Ispitanik 1: Smatram da su časovi korisni i da se može dosta naučiti, svakako znamo više nego što smo znali pre ovog kursa, $i$ po pitanju znanja španskog jezika i gramatike i po pitanju znanja srpskog, ali i samog prevođenja sa španskog na srpski.

Ispitanik 2: Prevod je sam po sebi zanimljiv, a i časovi su takvi da svaki put saznam nešto novo.

\section{Literatura}

AlQinai, J. (2011). Training Tools for Translators and Interpreters. Jordan Journal of Modern Languages and Literature, 3 (1), 19 - 38.

Campbell, S. (1998). Translation into the Second Language. London: Longman.

Cerezo Merchán, B. (2013). La formación en Traducción Audiovisual en España: Un estudio de caso empírico-descriptivo. Trans, Revista de Traductología, 17, 167 - 183.

Eraković, B. (2009). Ilustrativni tekstovi kao nastavno sredstvo u obuci budućih prevodilaca. Godišnjak Filozofskog fakulteta u Novom Sadu, XXXIV, $171-179$. 
Eraković, B. (2010a). Successful Communication in a Beginner's Translation Class, or How to Help Students Develop Interpersonal Sub-competence. Scientific Bulletin of the "Politehnica" University of Timişoara Transactions on Modern Languages, 9 (1 - 2), 40 - 51.

Eraković, B. (2010b). Instrumenti ocenjivanja prevodilačke kompetencije u nastavi. Metodički vidici, 1 (1), 90 - 95.

Eraković, B. (2013). The role of translation diaries in the acquisition of theoretical translation concepts at the beginner level. Professional communication and translation studies, $6(1-2), 149-156$.

Eraković, B., Kampmark, N., \& Ivanović Muždeka, N. (2014). O Poarou u prevodu na srpski i maloj prevodilačkoj radionici u velikom projektu. U T. Prćić (izvršni urednik), Engleski jezik i anglofone književnosti u teoriji i praksi (pp. 533 - 550). Novi Sad: Filozofski fakultet.

Furmanek, O. (2010). Applied Interpreting Studies at the core of teaching the instructors: a proposal of solutions. The Journal of Specialised Translation, 14, 80 - 99.

García López, R. (2001). Teoría y didáctica de la traducción. En A. Barr, M. R. Martín Ruano \& J. Torres del Rey (Eds.), Últimas corrientes teóricas en los estudios de traducción y sus aplicaciones (pp. 239 246). Salamanca: Ediciones Universidad de Salamanca.

Gile, D. (2004, July). Integrated Problem and Decision Reporting as a Translator Training Tool. The Journal of Specialised Translation, 2, 2 - 20.

Katan, D. (2008). University Training, Competences and the Death of the Translator: Problems in Professionalizing translation and in the Translation Profession. In M. T. Musacchio \& G. H. Sostero (Eds.), Tradurre: Formazione e Professione. Padova: CLEUP.

Kelly, D. A. (2002). Un modelo de competencia traductora: bases para el diseño curricular. Puentes, 1, $9-20$.

Kelly, D. A. (2005). A Handbook for Translator Trainers. Manchester: St. Jerome Publishing.

Kelly, D. A. (2008). Realismo profesional y progresión pedagógica: una propuesta de criterios para la selección de materiales para la formación de traductores. Trans, Revista de Traductología, 12, 247 - 258.

Kelly, D. A. (2010). Translations didactics. In Y. Gambier \& L. van Doorslaer (Eds.), Handbook of Translation Studies 1 (pp. 389 - 396). Amsterdam/ Philadelphia: John Benjamins B. V. doi: 10.1075/hts.1 
Kelly, L. G. (1979). The True Interpreter. A History of Translation Theory and Practice in the West. Oxford: Basil Blackwell.

Kiraly, D. C. (1995). Pathways to translation: Pedagogy and process. Kent: Kent State University Press.

Kiraly, D. C. (2000). A Social Constructivist Approach to Translator Education. Empowerment from Theory to Practice. Manchester: St. Jerome Publishing.

Kovačević Petrović, B. (2015). Dramaturško-prevodilačka beleška. Na tragu Bihnera i Lorke. Scena, LI (3), 80 - 81. [on-line]. Dostupno preko http://www.pozorje.org.rs/scena/scena153.pdf [6. 4. 2016]

Künzli, A. (2004, July). Risk taking: trainee translators vs professional translators. A case study. The Journal of Specialised Translation, 2, 34 - 49.

Kussmaul, P. (1995). Training the Translator. Amsterdam/ Philadelphia: Benjamins.

Liu, J. (2013, January). Translators Training: Teaching Programs, Curricula, Practices. Journal of Language Teaching and Research, 4 (1), 127 - 132. doi:10.4304/j1tr.4.1.127-132

Mayoral Asensio, R. (1993). Didáctica de la traducción. La traducción de textos literarios en la formación de traductores no literarios. Conferencia pronunciada en las I Jornadas de Traducción Literaria y su Didáctica. Círculo de Traductores \& Universidad de Sevilla. Sevilla, 26 de marzo de 1993.

Mayoral Asensio, R. (2003, 10 - 11 noviembre). El traductor: educación y formación, ejercicio y aprendizaje. Actas VI Seminário de Tradução científica e técnica em língua portuguesa. A Profissionalização do Tradutor. Lisboa: União Latina.

Piletić, D. (2013). Prevođenje na univerzitetskim studijama italijanskog jezika i književnosti: od školskog prevoda ka sticanju prevodilačke kompetencije (neobjavljena doktorska disertacija). Filozofski fakultet, Nikšić.

Samardžić, M. (2008). Studentski prevod između školskog i profesionalnog ocenjivanja. U J. Vučo (priredila), Evaluacija u nastavi jezika $i$ književnosti (pp. 133 -144). Nikšić: Univerzitet Crne Gore.

Sawyer, D. B. (2004). Fundamental Aspects of Interpreter Education. Curriculum and Assessment. Amsterdam/ Philadelphia: John Benjamins Publishing Company. 
STICANJE PREVODILAČKE KOMPETENCIJE

NA UNIVERZITETSKIM STUDIJAMA ŠPANSKOG JEZIKA U SRBIJI

Marijana R. Aleksić

\section{Resumen}

\section{LA ADQUISICIÓN DE LA COMPETENCIA TRADUCTORA EN LOS ES- TUDIOS UNIVERSITARIOS DE LA LENGUA ESPAÑOLA EN SERBIA}

Como en Serbia aún no existen programas para la formación de traductores profesionales a nivel académico, el objetivo de este artículo es recalcar la importancia de los cursos de traducción en los estudios universitarios de lenguas extranjeras. Nuestra intención ha sido presentar los cursos de la traducción del español al serbio en la Facultad de Filología en Belgrado y en la Facultad de Filología y Artes en Kragujevac. Dichos cursos están bien concebidos, pero creemos que deberían ser ampliados. A saber, la idea principal de este artículo es que estas Facultades, a falta de debidos programas académicos para la educación de traductores, deberían encargarse de la formación en cuestión.

Palabras clave: competencia traductora, formación de traductores e intérpretes en los estudios universitarios de lenguas extranjeras, realismo profesional, evaluación 


\section{PRILOG I}

Godina studija:

Fakultet: $\mathrm{u}$

Pitanja se odnose na sve kurseve prevođenja sa španskog na srpski jezik u toku osnovnih studija.

1. Na kojoj godini počinju kursevi prevođenja i koliko semestara traju?

2. Da li smatrate da nastava prevođenja treba da se izvodi od prve godine osnovnih studija?
a) $\mathrm{Da}$
b) $\mathrm{Ne}$
c) Možda

3. Da li vas interesuje prevođenje? Koje vrste prevođenja? Da li biste želeli da se bavite prevođenjem?

4. Koliko studenta u proseku ima u grupi na kursevima prevođenja?
a) Manje od 10
b) Između 10 i 15
c) Više od 15

5. Da li smatrate da prevođenje može da bude u funkciji učenja jezika?
a) $\mathrm{Da}$
b) $\mathrm{Ne}$
c) Ne znam
Komentar:

6. Da li ste na časovima prevođenja imali i teorijsku i praktičnu nastavu?

a) Samo teorijsku

b) Samo praktičnu

c) I teorijsku i praktičnu

7. Da li pored znanja stranog jezika prevodilac treba da poznaje i druge oblasti? Obrazložite odgovor. 
8. Da li se od studenata očekuje da aktivno učestvuju u nastavi prevođenja?
a) $\mathrm{Da}$
b) $\mathrm{Ne}$

Komentar:

9. Da li profesor/ka daje konačno rešenje ili dolazi do rešenja zajedno sa studentima i uvažava različite varijante?

10. U tabeli označite ona polja koja se odnose na gradivo koje je bilo zastupljeno na kursevima prevođenja.

\begin{tabular}{|l|l|l|}
\hline & Teorijska nastava & Praktična nastava \\
\hline Književno prevođenje & & \\
\hline Simultano prevođenje & & \\
\hline Konsekutivno prevođenje & & \\
\hline Audio-vizuelno prevođenje & & \\
\hline $\begin{array}{l}\text { Stručno prevođenje } \\
\text { (medicina, umetnost, ekologi- } \\
\text { ja, ekonomija, pravo itd.) }\end{array}$ & & \\
\hline
\end{tabular}

11. Ukoliko ste imali teorijsku i/ ili praktičnu nastavu iz audio-vizuelnog prevođenja, bavili ste se (možete zaokružiti više opcija):
a) filmovima
b) dokumentarnim programima
c) humorističkim programima
d) naučnim emisijama
e) drugo:

12. Da li smatrate da su u nastavi prevođenja dovoljno zastupljene sve vrste tekstova (dramski, pravni, naučni itd.)?
a) $\mathrm{Da}$
a) $\mathrm{Ne}$

Komentar: 
13. Da li na časovima imate pristup internetu i štampanim resursima koji bi mogli da vam budu od pomoći? (Kada je u pitanju prevođenje kod kuće pristup se podrazumeva)
a) $\mathrm{Da}$
b) $\mathrm{Ne}$

14. Da li ste na časovima prevođenja imali priliku da se upoznate sa softverom za prevođenje (barem u teoriji)?
a) $\mathrm{Da}$
b) $\mathrm{Ne}$

15. Možete li da navedete neki program za prevođenje?

16. Da li je važno da se prevodilac upozna sa životom i delom autora?
a) $\mathrm{Da}$
b) $\mathrm{Ne}$
c) Ne znam
Komentar:

17. Da li je važno da prevodilac sagleda širi kontekst dela: nameru autora, vremenski i prostorni okvir, funkciju teksta u izvornoj kulturi, funkciju teksta u ciljnoj kulturi, kao i vrstu teksta, temu, lingvističke odlike teksta itd.?
a) $\mathrm{Da}$
b) $\mathrm{Ne}$
c) Ne znam

18. Da li mislite da je poznavanje kulturnih razlika značajno za prevođenje?
a) $\mathrm{Da}$
b) $\mathrm{Ne}$
c) Nisam siguran/na
Komentar: 
19. Da li smatrate da su vas kursevi prevođenja koje ste imali na fakultetu pripremili za profesionalno bavljenje prevođenjem?
a) $\mathrm{Da}$
b) $\mathrm{Ne}$
c) Delimično
Komentar:

20. Da li vas časovi prevođenja dovoljno motivišu da se bavite tom profesijom?
a) $\mathrm{Da}$
b) $\mathrm{Ne}$
c) Delimično
Komentar:

21. Ukratko opišite kako izgleda tipičan čas prevođenja (sa španskog na srpski).

22. Ukratko opišite kako su izgledali kolokvijumi i ispiti koje ste dosad imali (prevođenje sa španskog na srpski). Koju ste literaturu koristili (jednojezični/ dvojezični rečnici itd.)?

Zaključni komentar:

HVALA! 